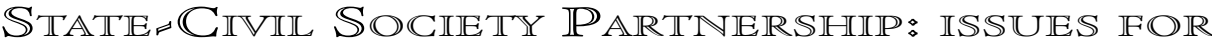 $\mathbb{D E B A T E} A \mathbb{N D} \mathbb{N E} \mathbb{R} \mathbb{R E S E A R C H} \mathbb{E} S$
}

\author{
Mário Vasconcellos* \\ Ana Maria de A. Vasconcellos**
}

\begin{abstract}
$\mathrm{n}$ this paper we look at the literature related to partnership between state and civil society, especially partnership between public and non-for-profit organisations. We discuss the differing perspectives of partnership and attempt to identify some of the main theoretical concerns 1 about partnership between state and civil society in the governance context. In this paper, we argue that the historical background of partnership has not been included among factors used in explaining the resort to partnership in governance. In spite of existing analyses showing that partnership brings social benefits in their own right, we try to show that there is no evidence that this 'social technology' contributes effectively to bringing power to powerless people and social groups. Most of the literature shows that partnership tries to make relationship between local people and local governance stronger and improve the possibilities for powerless people and social groups to participate in local governance. However, we do not find clear evidence in the literature that partnership allows for a shift in political power. Finally, we show that it is unclear whether the interaction between ordinary people and the state through a participatory process has successfully helped to build social cohesiveness for different social groups. The main contribution of this paper is to expand the understanding of the factors that influence the process of partnership between state and civil society (positively and negatively) for local development.
\end{abstract}

Keywords: Partnership. State-Civil Society Partnership. Governance. Empowerment. Social Capital.

Parceria entre o Estado e a Sociedade Civill: pointos para o debate e novas pesquilisas

Resrimo

N este artigo analisamos a literatura de parceria entre o estado e a sociedade civil, em particular sobre a parceria entre as organizações públicas e as organizações sem fins lucrativos. Discutimos as diferentes perspectivas do conceito de parceria e objetivamos destacar algumas das principais preocupações teóricas sobre este conceito no contexto da governança. Buscamos mostrar que, em geral, o contexto histórico da parceria não tem sido incluído entre os fatores usados para explicar o seu uso no contexto da governança. Apontamos que, a despeito das análises sobre parceria que indicam que esta traz benefícios sociais, ainda existem lacunas no conhecimento que evidenciem que esta "tecnologia social" contribui efetivamente para empoderar as pessoas e os grupos sociais com menor poder de influência. A maior parte da literatura sugere que a parceria objetiva fortalecer a relação entre a população e - governo local e melhorar as possibilidades das pessoas e dos grupos sociais com menor poder de influência em participar na governança local. Entretanto, não encontramos na literatura sobre parceria evidências substantivas de que ela se direciona para modificar a estrutura de poder político. Finalmente, mostramos que não está claro se a interação entre as "pessoas comuns" e o estado, por via de um processo participativo, tem contribuído efetivamente para construir coesão social para diferentes grupos sociais. A principal contribuição do artigo é expandir o conhecimento dos fatores que influenciam (de forma positiva e negativa) o processo de parceria entre o estado e a sociedade civil para o desenvolvimento local.

Palavras-chave: Parceria. Parceria Estado-Sociedade Civil. Governança. Empoderamento. Capital Social.

* PhD pela Universidade de Swansea - Reino Unido. Professor da Universidade Federal do Pará - UFPA e da Universidade da Amazônia - UNAMA, Belém/PA/Brasil. Endereço: Cidade Universitária José da Silveira Neto, Núcleo de Meio Ambiente. Belém/PA. CEP. 66.075-110.Email: mariovasc@ufpa.br

** PhD pela Universidade de Swansea - Reino Unido. Professora da UNAMA, Belém/PA/Brasil. Email: annavasc@unama.br 
$\int$ $\mathrm{n}$ this paper we explore the literature related to partnerships between state and civil society with particular emphasis on the partnership between public and nonfor-profit organisations. We discuss the differing perspectives of partnership and try to point out some of the main theoretical concerns about partnership in a governance context.

The paper is organised into five sections including this initial one. The following section deals with definitions of partnership and focus on its structure and meaning. We examine the concept of partnership based on the literature about social capital, rural development and partnership theories. In the third section we deal with two factors that act on partnership building; social networks and decentralisation. The goal of the third section is to show how partnership emerges from the influence of both societal structure and the roles of the state. In the third section we also deal with issues of good governance. In the fourth section we shift the debate from partnership dimensions to organisational factors that have an influence on them. Our aim in the fourth section is to demonstrate how management structures and partnership procedures affect its efficiency. In conclusion, we reconnect in the fifth section the analysis undertaken in the course of the paper and map out the main issues of the conceptual ground in which the relations between local organisations (LO) and state should be analysed.

\section{The MIearnings and Structrures of Parrinership}

In this section, we examine the concept of partnership as presented in the literature on rural development, governance and social capital. We focus on partnership structures and meanings which have been assumed in the different fields of knowledge. We aim to establish a working definition for partnership in the context of this paper.

The term partnership has obtained a diversity of meanings which McQuaid (2000, p.10) suggests range along an infinite spectrum. Partnership contains a sense of cooperation, mutual trust and synergy between individuals and organisations needed to achieve a common objective. On this basis, partnership is concerned with the relationship between two or more stakeholders putting together different resources with the purpose of jointly achieving common aims (MCQUAID, 2000; LEWIS, 2000). First, partnership is a form of organisation in which the achievements of the partners engaged depends on the existence of trust (FOWLER, 1997; HARRISS, 2000) and self-organisation (HARRISS, 2000, p.231). In this context, partnership motives are not shaped by ideas of material gain or coercion of the engaged partners, but by a sense of common purpose supported by trust between its actors. Partnerships based on trust evoke the notion of partnership as a prolonged process and as the result of a long-standing relationship between actors (LEWIS, 2000).

Harriss (2000, p. 236) suggests that this type of partnership is an 'ideal type of cooperation' and Fowler $(1997 ; 1998)$ views it as an 'authentic partnership'. Partnerships based on trust are understood to be a result of networking skills and motivation of actors (FOWLER, 1997; HARRISS, 2000) Such partnerships are characterised by a focus on actors, on their independence and enthusiasm in sharing values and visions to achieve a common objective. Partnership based on trust is associated with the idea of stakeholders working together for mutual benefit, voluntarily sharing values and goals in embedded relations (OSTROM, 1997) In this perspective, the intention of the partners depends on commitment rather than on external factors because partnership can only exist if there is a basic trust between partners, as Thompson (2005, p. 31) points out.

Although partnership based on trust possibly represents an 'authentic type' of cooperation, as pointed out by Fowler (1997), and is "understood as mutually enabling, interdependent interaction with shared intentions" (FOWLER, 1997, p.107), many partnerships are very different from this primary concept of trust. As Tendler (1997) and Evans (1997) argue, cooperation, levels of trust and self-organisation are influenced by the incentives and opportunities created by the prevailing institutional frameworks. 
In addition, any partnership relationship is involved in inevitable risk and uncertainty (THOMPSON, 2005, p.29). Trust is hard to produce and maintain (BOVAIRD; LOEFFLER, 2005, p.153) in any society because of its permanent changes. In societies where distrust is dominant, the production and maintenance of trust is harder (VASCONCELLOS SOBRINHO, 2009).

Second, partnership is most commonly found in formal and political institutions (DFID, 2006; EVANS, 1997; TENDLER, 1997; WORLD BANK, 2005). Partnership is centred on institutional frameworks and governments (DFID, 2006; EVANS, 1997; TENDLER, 1997; WORLD BANK, 2005) This perspective emphasises partnership as shaped by the rules, regulations and governmental actions where it emerges (WORLD BANK, 2005). From this viewpoint, the nature of regulatory frameworks, of the incentives and sanctions of supportive institutions promoting and valuing innovation influences the prevailing level and type of cooperation. Partnerships centred on institutions are related to the notion of complementarities (EVANS, 1997) between organisations under the guidance of a formal structure of authority. Actors' complementarity, which is specially built in a formal and political environment, focuses on 'problem solving' to present a solution to a particular societal problem. The evidence of 'successful' problem solving (FERREIRA, 2003) induces the idea that partnerships can be built up in a short time.

Nonetheless, as argued by Giddens (1991), relationships depend on the mutual commitment of the partners involved, who only remain in the relationship for as long as they choose to. The purposes of the partners depend on commitment rather than on external anchors, and partnership can only exist if there is mutual trust between partners (GIDDENS, 1991). Partnership implies that trust is a coping mechanism by which actors can address risk and uncertainty in communities. This is especially true when a new climate of risk increases public sensitivity to a level that has to be faced by them.

A common feature of all forms of partnership is that they represent a relationship that involves power sharing (HODGETT; JOHNSON, 2001, p.324). However, addressing unequal power relations between partners is still a great challenge to the discourse and practice of partnership in general (JOHNSON; WILSON, 2006) and particularly for partnerships based on formal and political institutions. In any relationship (even relationships based on trust) partners always have differences that may partially derive from their assumptions, perspectives, expectations or agendas (JOHNSON; WILSON, 2006). Furthermore, partnership actors bring their own specific sets of power positions, roles and responsibilities as determined by values, skills and organisational resources into the network arena. A sceptical view of the power relations debate is that mutual partnerships are not possible because of the existence of permanent power inequality between partners (AHMAD, 2006).

Be that as it may, partnerships are relationships of self-interest between those who see an advantage in them. Partnerships have been built even when the partners do not share the same values, goals and ways of working together. As argued by Johnson and Wilson (2006, p. 71), difference is a driver for mutuality inside partnership arenas. This point to the idea that partnership stands on mutuality (BRINKERHOFF, 2002) and is not based solely on sharing. Additionally, partnership is also based on difference, which is an opposite point of view stating that mutuality in partnership is not possible because of inequality, especially unequal power relations (AHMAD, 2006). New mechanisms of trust need to be created, mainly where there is a range of organisations and development agencies that bring their own specific sets of power positions to partnership relations.

In the public governance context, partnership is based on various perspectives, but at least two predominate: partnership as a form of participation (community/popular participation and social participation) and partnership as a tool for development management. They have been debated, in turn, in various ways.

In community participation, partnership is considered the most suitable approach for sustainable development and service delivery in rural areas (CHAMBERS, 1983). The authors' argument is that partnership seeks to promote community participation in decisions that affect themselves (CHAMBERS, 1983). However, this perspective 
reveals a simplistic understanding of community as that of a harmonious group within which people share common interests and needs, and this conceals power relations (CLEAVER, 2002). In spite of a key intention to assure the full and active participation of community members in the rural programmes that affect them, evidence suggests that partnership as a mechanism of participation has not worked effectively towards social inclusion and power-sharing (BOWYER, 2003; CLEAVER, 2002; TORO, 2005).

Social participation, which emerged in response to an earlier normative understanding of partnership for inclusion and power-sharing of the powerless, is recurrently used as an instrument to involve members of different sectors of society. Social participation is deemed important for promoting access to basic needs and basic human rights (CAMAROTTI; SPINK, 2000); particularly by poor rural people (WORLD BANK, 2004). Also under the rationale of participation, this perspective prioritises enduring relationships for strategic issues such as fighting poverty and creating sustainable livelihoods rather than 'immediate problem solving'. This perspective can be found in international donor, governmental, and corporate materials: mission statements, annual reports, strategic planning efforts, special reports, programmes and project documentation (DFID, 2006; WORLD BANK, 2005). According to these organisations, partnership is an appropriate vehicle for addressing social and economic needs with the involvement of all sectors of society. It is a mechanism for promoting the participation of civil society in the planning and management of long term public programmes, thus minimising conflicts between divergent actors in favour of society at large (WORLD BANK, 2005).

However, this perspective faces a real problem in moving from the project level up to the level of public policy. The social problems that partnership in this perspective intends to fight are much more complex than the mechanisms available to the projects of the multilateral organisations.

Under development management (which is usually theoretically supported by the New Public Management movement), partnership is an instrument to be used to reach more precise objectives typically associated with effectiveness, efficiency and responsiveness (WORLD BANK, 2005). Partnership is treated not just as an instrument of popular participation in public actions. Instead, it is viewed as a method of combining public and private resources to effectively and efficiently carry out specific public programmes. In spite of the instrumental meaning assumed by partnership in the development management perspective, there is a set of interconnected ideas under which partnership is examined in an analytical way. One of the ideas focuses on the relationships between governments, NGOs, and donors, on advocacy-policy versus programme implementation and corporate citizenship (AHMAD, 2006). Its focus is on effective partnership. On a broader scale, it deals with the exercise of power and how this influences the success of a partnership. It criticises the power of governments and donors and suggests the possibility of a zero-sum power relationship (AHMAD, 2006). In spite of the insights about the influence of power on partnership, the pessimistic trend underlying this interpretation does not offer alternative ways to overcome the negative criticism pointed out here. It suggests neutral power relationships that in fact do not happen in reality.

A second group of ideas related to partnership deals with its own efficiency. Here partnership is a strategic mechanism for resource complementarities between public and private organisations and is also a cost-efficient mechanism to carry out developmental projects at low cost and high performance (BENNETT; KREBS, 1994). Partners seek out connections with third parties who can help in managing strategic interdependencies efficiently. The rationales for a complementarity of resources and cost-efficiency assume narrow characteristics because partnership is only used for budget expansion or to balance out economic costs with project outcomes (BENNETT; KREBS, 1994). The complementarity rationale focuses on economic ends and views social aims as a consequence of resource efficiency.

Also concerned with economic outcomes, another group of ideas comes from the literature on business alliances. Partnership terminology in this context is evolving and increasingly refers to less exclusively formal relationships, as opposed to the limited, 
historical application of the legal structures, mergers and contracting relations. In order to attain efficient and effective outcomes (BENNETT; KREBS, 1994), this concept refers to equality in decision making and autonomy of the partner organisations and corporate citizenship. However, it has a limited focus on the public-private relationship for market purposes. In spite of the importance of market orientation in partnerships with economic ends, the public sector is not pursuing purely commercial goals. A criterion for partnerships is that it should involve public bodies in balance with social issues (MCQUAID, 2000, p.11).

A fourth set of ideas includes political economics and networking theories. In this thread inter-organisational relations are examined, particularly those between the public and private sectors, which include civil society. Despite its normative slant, this approach is the most analytical within partnership literature. It deals most rigorously with the identification and examination of the inter-organisational coordination challenges, incentive systems, control mechanisms and structural alternatives. These have emphasized the importance of the interrelationships between the political and the social context within networks. However, the theoretical and empirical validity of these views needs further analysis (MCQUAID, 2000, p.30). So far, there is no clear understanding about the behaviour and policies of organisations involved in partnerships for economic development. Moreover, the nature of their relationships with networks and partnerships between actors not directly involved in partnership at the local level (including the flows of resources, power and information within the networks) is not included in the analysis.

The reassessment of the relationship between state and civil society made possible by the theory of social capital throughout the 1990s (COLEMAN, 1990; PUTNAM, 1993; EVANS, 1997) has raised the issue that organisational and institutional constraints coming from individual social networks actually contribute to inefficient political structures, economic fragility and social fragmentation. Social capital in Coleman's (1990) and Putnam's (1993) terms relates to features of social life such as trust, norms and social networks that facilitate co-ordinated action and enable participants to act more effectively in pursuing shared objectives.

In spite of the arguments that any society is characterised by networks of interpersonal communication and exchange, both formal and informal, as argued by Coleman (1990) and Putnam (1993), an understanding of how social capital has affected recently formed societies has not been confirmed. Studies about publicly engaged civic organisations and about their socio-political and economic effects mostly concentrate on advanced industrial countries. These studies indicate that the capacity of a society to produce social capital among its citizens is supported by its long-term experience working with social organisation. However, for recently formed societies, as argued by Fox (1997), trust, norms of reciprocity and social networks are rare and social capital is substituted by hierarchical politics.

According to Isham et al. (2002), only a few studies about societies deprived of trust have underlined the role of social capital in overcoming market failures and building democracy. So far, the studies on social capital in developing countries have been mostly oriented toward the economic and political effects of social capital (ISHAM et al., 2002; TENDLER, 1997) and only a few analyses have examined the mechanisms through which these effects happen.

As argued by Fox (1997), in Latin America, where trust and social engagement are in great need, analyses on social capital focus on the interaction between government and civil society as part of a strategy intent on stimulating better service provision by the government. Additionally, it has focused on the conflicting relationship between government and citizenry living in less than democratic conditions (FOX, 1997). Recently social capital analysis in Latin America has stressed the importance of social networks for getting public outcomes (TENDLER, 1997) rather than the mechanisms through which these networks are created.

In spite of literature (FOWLER, 1997) indicating that there is a direct correlation between social capital and partnership, so far it is not clear whether a social network of one group of organisations is any more effective than the social network of another 
group in working as partners and promoting development. This means that any analysis of any group of organisations working in partnership will hopefully be more revealing if information about them and their capacity of interaction to effectively produce social change by structural transformation is examined (ENGBERG-PEDERSEN; WEBSTER, 2002). This is the case for three basic reasons. First, it is not always the case that the capacity of organisations to perform effectively as a network best serves the interests and priorities of their members. Effective connections between organisations do not automatically result in the building of social capital. Second, despite the fact that social capital contributes to an understanding of how actors engage with each other through markets, state and civic society, this form of capital is still somewhat intangible (FINE, 2001). Despite efforts being made to measure social capital, there is still no consensus on how this can be done (FINE, 2001). Third, the process through which social capital may also hinder mechanisms of interaction between certain actors means that an understanding of informal relationships within and between institutions and organisations is still critical.

In order to understand how organisations and their networks influence partnerships with government, an analysis of the social environment and of the socio-political dynamics in which they operate is of critical importance. In this context two factors have been pointed out as relevant: (a) the level of social trust (HARRISS, 2000); and (b) the operational capacity of the established social networks (FOX, 1997). With the purpose of addressing these factors, an analysis is required of a number of other related issues that affect access to information and composition of the social structure, including variations in the political context, geography and environmental diversity (BOWYER, 2003).

In areas of strong vertical social structures based on relationships of authority and power, it is argued that the potential for collective action among ordinary people and their organisations is more restricted (FOX, 1997; BOWYER, 2003; VASCONCELLOS SOBRINHO, 2009). The level of social trust and the operational capacity of social networks to bring about fundamental changes to the structures of politics and social relations are weakened. This suggests that the impact of hierarchy and social fragmentation upon the operational capacity of social networks and the level of social trust are surely critical factors. In this respect, it is worthwhile investigating whether social networks are a valid method for improvement in case citizens' capacity for collective action is restricted and access to and influence over state and market is not feasible. Social networks should be analysed in order to show how much capacity they have to influence the formation and support of partnership with government for the improvement of the rural sector (BOWYER, 2003; VASCONCELLOS SOBRINHO, 2009).

The capacity of social networks to give ordinary people the means to advance mutual interests and challenge authority is subject to a number of influences. First among these is a lack of clarity about the relationship between member organisations inside a social network. It is argued that interaction is predicated upon regular exchange of information shared by all the various member organisations. Secondly, physical and social constraints make information access weak (PUTNAM, 1993). It is argued that the context in which the interaction occurs is as important as the consequences that it has and the changes that it elicits. Thirdly, practical constraints such as geography, location, and transport affect the spreading of information (BOWYER, 2003). Finally, the type and quality of information available to member organisations inside a social network are also vital. For the two last factors, it is argued that the type of information presented to member organisations in a social network is subject to the negative influence of difficulties of geographical access, transport and communication. Bowyer (2003), for example, states that geographical discrimination, remoteness, location, transport and communication make rural communities more vulnerable to poverty. This indicates that the capacity of social networks to act effectively does not depend only on the information to which each member has access, but also on the practical difficulties that influence the dissemination and the quality of that information.

It has also been pointed out that the single greatest obstruction to effective social networks derives from the political effects that emerge when they seek to generate extensive trust, particularly across a fragmented social and economic environment 
(FOX, 1997). It is argued that a number of political transformations are required to allow excluded groups of rural people to come to take part in decision making, political action and policy development (ENGBERG-PEDERSEN; WEBSTER, 2002).

From effective social networks it is expected that an environment of local action in association with state, organisations and other institutions will encourage horizontal collective action as well a promotion of social transformation, which is to say partnership with social transformation. It is only possible to assess the contribution of social networks in realising partnership with social transformation if the meaning of social transformation is seriously examined. To this end, a commitment to organisational restructuring and a support for the creation of organisational mechanisms to promote decentralised and multiple-stakeholder decision making are relevant factors for further examination.

For the purpose of investigating the effects of these factors on the level of social inequalities in the rural sector, it makes sense to analyse the accumulation of material related to the arrangements already in place as well as the changes that occur amongst the different groups involved in the process of partnership. The possible effect of social capital depends on the nature of the economic goods that development partnerships intend to bring about.

Partnership does not only depend on social factors but also on political aspects. Of the political aspects decentralisations is the one that has exerted the highest influence on democratisation, popular participation and participatory governance (CAMAROTTI; SPINK, 2000; RONDINELLI, 2006). The next section discusses how decentralisation acts on partnership building and consequently on governance.

\section{Partunership, Decentralisation and Governance}

Our main objective in this section is to show how partnership emerges from the influence of the roles of the state. Here, we also deal with issues of good governance. We intend to demonstrate that partnership has been perceived as a way of introducing a wider developmental dimension into the debate of governance. However, we show that the discussion on power and empowerment has been left out of the good governance debate. Thus, we discuss the main role that empowerment takes in partnership for development at the local level.

Decentralization is of an incomparable importance as a political strategy to distribute political power within the state system as well as a way of linking social and political groups to the political decision-making process and to the allocation of public resources (RONDINELLI, 2006). Despite this political connection, decentralisation is generally accepted as an essential factor for social development policy and as an important mechanism for any improvement in the performance of the public sector (BLAIR, 2000).

However, the merit of decentralisation depends on how it is defined, how it is politically used, and how it is put into practice. For example, Smoke (2003, p. 7) emphasises that despite efforts being made to support decentralisation, many of them would seem to be no more than devolution. In some African countries, decentralisation efforts are, at least in part, used as a guise for renewed attempts by the national political elite to expand its control through the development of new local institutions or the reconstruction of old ones. Mehrotra (2006) focuses on the state as a funding agent and a provider of services and points to questions about the type of governance reforms that are needed to reduce state failure in delivering basic social services. In most developing countries the state delivers development services in a top-down bureaucratic manner through sectorial line ministries down to the local level (MEHROTRA, 2006, p.265). But this means of service delivery misses one of the greatest sources of technical efficiency in the use of resources - the synergy of interventions in the various social sectors (MEHROTRA, 2006).

Decentralisation and enhanced local governance are associated with the movement for democratisation that has spread all over the world beginning in the 1970s. 
With the end of the military regimes in Latin American countries such as Brazil and Argentina, many national and local elected officials and political opposition groups resorted to decentralisation as a way of building democratic institution (SPINK; CLEMENTE; KEPPKE, 1999; RONDINELLI, 2006). At the beginning of the 1990s, there was an increasing acknowledgment that even if hierarchical control was not a successful way of delivering public services, administrative decentralisation was still deemed necessary. In addition, the 1990s saw a spread of democratic regimes in the developing world. More than one hundred countries now have democratically elected a government which is almost double the number of those at the end of the 1980s (MEHROTRA, 2006, p. 271).

However, decentralisation policies have been implemented successfully in some countries but not in others. There are differences in the degree to which individual countries have adopted reforms. The region of the world that has responded mostly to democratic reforms since the 1970 s has been Latin America, where, at present, a very high proportion of countries enjoy functioning electoral democracies (MEHROTRA, 2006). In Latin America, as national governments have become democratised following the shedding of autocratic and military regimes during the $1980 \mathrm{~s}$, local governments and local councillors, regional officials and other executive officers have come to office to serve their constituents (BOWYER, 2003).

For Rondinelli (2006, p. 400), the success of decentralisation depends on effective policy implementation. How policies are implemented is as important as how they are devised. Ultimately, decentralisation - especially delegation, devolution and privatisation - involves wide institutional development and managerial capacity building at the local level (RONDINELLI, 2006). According to Rondinelli, the poor results of experiments with 'deconcentration' and weak devolution in Cambodia have been attributed to the implementation of decentralisation policies. The success of decentralisation is associated with strengthening the administrative and political capacity of those organisations which have been charged with responsibility and authority (RONDINELLI, 2006). However, decentralisation as redistribution of administrative responsibilities and transfer of functions from central government to local ones does not mean transference of powers in an administrative and political sense. Shifts in responsibilities and resources from central government to lower level governments do not mean automatic benefits in the participatory process, especially in the case of more vulnerable people (BOWYER, 2003; TORO, 2005). A decentralisation process that fails to engage in distribution and operation of power is likely to offer little help to marginalized groups. On the contrary, in some cases decentralisation has strengthened the power of the local elites and solidified client-patron relationships (VASCONCELLOS SOBRINHO, 2009).

According to Carney (1995), decentralisation increases local influence on government, improves information flow, speeds decision making, promotes a better ability to target the poor and increases opportunities for partnership (CARNEY, 1995, p.2). However, specific forms decentralisation should take to be beneficial will vary across countries according to their different political, institutional, fiscal and cultural characteristics. Smoke (2003) argues that the history and traditions of a country will determine what makes sense. The political context - nature and competitiveness of political parties, their power at the local level and the strength of civil society - is of particular importance (SMOKE, 2003). This point of view refrains one from thinking of decentralisation as merely a redistribution of administrative responsibilities and a transfer of functions from central government to local ones. It underlines the existence of different elements in decentralization.

Despite all the enhancements decentralisation is expected to further or meant to further, problems do arise during its implementation. Much of the decentralisation literature focuses on its often problematic performance, and positive writings tend to be based on anecdotal instances of success or enthusiastic rhetoric about its benefits. In spite of limited empirical evidences supporting decentralisation positive effects and clarifying how to grasp its potential benefits, policy makers seem to be willing to push it forward in many countries anyway. 
There are also several issues connected with governance that impact decentralisation. Bowyer (2003), for example, identifies four contextual factors affecting the achievements of decentralised institutions. These comprise powers to influence the local environment, including development activities, financial resources, administrative capacity and accountability mechanisms. However, all of these issues imply a close relationship between civil society and state (GAVENTA, 2004, p.25) in pressing for citizens' rights. Local representative bodies need to have powers over the resources affecting their constituencies in order to become legitimate actors around whom civic organisations and citizens can rally for justice, sustainable livelihoods and economic improvement.

In the context stressing the importance of the engagement of civil society with the state (GAVENTA, 2004, p. 25), the discussion about partnership is accompanied by a concern for 'good governance' (TENDLER, 1997). In its relation with partnership, good governance means new forms of relationships between ordinary people and their government with the purpose of carrying out development programmes that involve transparency, accountability and economic improvement of public services (World Bank, 2004). The idea of decentralisation for good governance advances the debate of the effective government commitment to the improvement of the efficiency of public services to reduce poverty, aid rural development and so on (WORD BANK, 2004).

Despite growing citizenry awareness, many challenges remain as to the strength of the idea of good governance by means of the relationship between civil society and the formal institutional structure of government (BOWYER, 2003). Considering that this relationship tends to be at the same time more visible and stronger at the local than at the higher levels of government, the trend for decentralisation has probably reinforced local initiatives in favour of improved governance (BOWYER, 2003). However, the limited roles, weak access to information, and feeble representation at the local level of government suggest that active involvement of agents of civil society who can count on an effective organisational capacity is restricted (BOWYER, 2003). This is due in part to political culture, political will and histories of state-civil society engagement (GAVENTA, 2004). As a result of the decentralisation process, new institutional arrangements for participatory governance have been considered; new mediating institutions like NGOs and committees are cases in point. For example, Barth (2006, p. 253) has deemed health management committees to be essential elements of the democratisation and decentralisation process in Brazil. According to Barth (2006) beside all the difficulties of representation, the committees help to create a new ethics of discourse based on recognition of and respect for differences.

The idea of decentralisation reinforces local initiatives for improved governance (STREN; CAMERON, 2005). Despite improvements brought about by committees with regard to the targeting of resources and government knowledge of local needs, institutional problems appear at its implementation stage (GAVENTA, 2004; VASCONCELLOS SOBRINHO, 2009). Myths and misconceptions about decentralisation lead to a final set of issues on how to approach decentralisation in practice. These include the form a decentralised system can and should most appropriately take the forces likely to support or undermine it, and the right pace of its implementation (GAVENTA, 2004; VASCONCELLOS SOBRINHO, 2009). The example given by Rondinelli (2006) shows that decentralisation varies in different national contexts. For example, in Africa decentralisation depends on the mechanisms experienced by decentralisation departments. Similar problems exist locally, where it is necessary to coordinate activities of local government councils and departments, central government field offices, traditional authorities and non-governmental organisations. However, one of the greatest deficiencies in most decentralisation efforts is the lack of coordination of the actors involved and the ensuing failure to build linkages among players of decentralisation at the national, intergovernmental and local levels (RONDINELLI, 2006).

As argued by Stren and Cameron (2005, p. 278), the idea of good governance through the relationship between civil society and the formal institutional structure of government is still a challenging one considering that this relationship tends to be at the same time more visible and more robust at the local than at the higher levels of 
government. In Brazil, for example, a key feature underlying the movement toward greater electoral accountability at the local level has been the growth and continuing strength of civil society. Organisational initiatives in rural areas show the importance of a suitable connection between local government bodies and their constituents which has been an important factor for increasing citizen involvement (VASCONCELLOS SOBRINHO, 2009).

The proneness to conflate decentralisation with democratisation and the increase in participation at the local level make many believe that decentralisation will lead to greater responsiveness to the 'poor' (GAVENTA, 2004). Although the majority of the populations in developing countries are at the same time poor and excluded from elite politics, any scheme offering political participation to ordinary citizens seems likely to increase their 'voice' and the relevance and effectiveness of a government policy (VASCONCELLOS SOBRINHO, 2009). Evidence from a group of selected sub-Saharan African countries with recent experience in decentralised government are reviewed in comparative terms and cases in which decentralisation has in fact successfully contributed to poverty reduction are taken into account (SMOKE, 2003).

Inspired by the discourse of decentralisation and partnership, the Brazilian federal government has sought to promote the idea of open government and participative administration (SPINK; CLEMENTE; KEPPKE, 1999; FLORISBELO; GUIJT, 2004; VASCONCELLOS SOBRINHO, 2009). This idea conveys the impression of a sharing of power, resources and responsibilities with the ordinary people (SPINK; CLEMENTE; KEPPKE, 1999; FLORISBELO; GUIJT, 2004; VASCONCELLOS SOBRINHO, 2009). However, in spite of the extensive decentralisation processes that have been put into practice in developing countries, there is little empirical evidence showing that it has contributed to the effectiveness hoped for.

Under the circumstances of decentralisation and good governance, the operational character of the organisations and institutions involved in the interactive process between civil society and government is of critical significance. Decentralisation and good governance have given new roles to former beneficiaries of government services. Proposals to shift decision-making process from central offices to local agencies have been encouraged to facilitate participatory development and accountability and also to transfer control over development activities to local communities and governments. However, as Barth (2006) and Vasconcellos Sobrinho (2009) argue, for those who see councils as an important instrument to make public management more efficient, the results achieved so far are quite disappointing.

Substantial barriers have come to hinder the social development so expected from the effort of decentralization. See, for instance, the opportunity decentralisation has given elite groups to further their own privileged interests, mainly in areas in which economic elites dominate the political scene (KOHL, 2003). This is clearly the case in areas where local organisations are not able to influence local planning in the direction of the interests of the whole community. As a result of decentralisation, the institution of a formal partnership between groups of local elites, the government and other local organisations may legitimise a structure favouring the privileges of the elites against the interests of the marginalised rural communities ( $\mathrm{KOHL}, 2003)$.

In order to control the manipulation of local people by the elite groups, Fowler (1997) argues that power should be shared equally amongst all agents involved in formal structures of partnership. The engagement of mediating institutions has allowed direct involvement of the local people in democratic methods of governance and actual citizen participation (FLORISBELO; GUIJT, 2004; BARTH, 2006). However, the failure of formal structures to deal with issues of power has come to mean that partnership is unlikely to bring automatic benefits to marginalised rural communities. Donors and NGOs pursuing decentralising programmes often sideline elected local authorities, owing to a general lack of confidence in any form of government (EVANS, 1997; TENDLER, 1997).

Decentralisation allows for stronger ties and connections among local elite members (KOHL, 2003, p.153) and failure to engage in distribution of power is likely to offer little help to marginalized or vulnerable groups (BOWYER, 2003). Although 
partnership builds the relationship between local people and local government in a more direct way and connects civil society and governments in new ways, it will not necessarily be more inclusive or more favourable to the poor (GAVENTA, 2004, p.25). For example, Ribot (2003, p. 55) shows that in Mali, where new laws give local governments control over forest management, many projects still circumvent those laws in favour of project-selected committees or 'customary' authorities, and thus custom is often a pretext for meddling with gender, caste and ethnic inequalities.

In sum, if decentralisation is to make any progress, a number of major challenges must be confronted (SPINK; CLEMENTE; KEPPKE, 1999; FLORISBELO; GUIJT, 2004; VASCONCELLOS SOBRINHO, 2009). As Rondinelli (2006) points out, there are three ways to implement decentralisation practices. One is to define an intergovernmental system that makes sense in the context of a particular country; a second is to create mechanisms for coordinating activities of the multiple actors invariably involved in decentralisation and to ensure that connections among the key dimensions of decentralisation will be built; a third is to develop a suitable strategy to implement decentralisation (RONDINELLI, 2006). However, the specific forms will vary according to the different political, institutional, fiscal and cultural characteristics of the countries involved. The history and traditions of a country will determine what makes sense, particularly in the short run but also in the long run. The political context the nature and competitiveness of political parties, their power at the local level and the strength of civil society is particularly worthwhile. Thus, it is critical to take stock from the beginning of what is feasible by taking into special account the delicate balance between developing a genuine local autonomy and maintaining justifiable levels of central control (RONDINELLI, 2006).

These features are part of Brazilian local governments, which have strengthened their autonomy and financial resources. However, there has been a limitation and some confusion as to the types of decentralisation initiatives adopted in recent years in Brazil. Local governments, for example, have encouraged or endorsed partnership because they believe partnership is more effective in assuring democracy and making civil servants more accountable and responsive to their citizenry. However, the effect is not always what is expected since it depends on the features and the type of decentralisation that is in place and the types of power relations concerned.

Proposals that advance partnership between local organisations and government by encouraging people to contribute to development programmes with their resources, skills and knowledge do not mean that governments work properly or that partnership leads to the empowerment of the community (BOWYER, 2003). Nevertheless, ideas related to a government role both in collaboration with and opposition to policy development are an aspect that inevitably will affect people's empowerment.

In spite of the fact that partnership may enable people to participate in government programmes as a way of empowering themselves, the effect of an unbalanced sharing of power on the capacity of people to conquer or use local political space is generally left unacknowledged (SEN, 1999; CLEAVER, 2001). The use of partnership in achieving political space to influence social transformation based on the political empowerment of the poor has been recast as an essential element by the neo-liberal programme development (WORLD BANK, 2004). According to this, empowerment is defined as giving moral authority to government agents to use local people's labour, knowledge and skills in the implementation of policy, especially in the rural world. Partnership phenomenon is dominated by effects/results and supposed effective mechanisms to achieve project objectives, but the empowering results one might expect from such a view are not clear (CLEAVER, 2001).

Increasing concern for social inclusion has expanded the notion of partnership beyond the implementation of particular projects to include much wider issues connected with the relationship between government and civil society (TENDLER, 1997). This means that partnership is no longer simply concerned with single issues. Instead, it is being associated with accountability, transparency and good governance (TENDLER, 1997; WORLD BANK, 2004). This means that partnership has been directly associated with equitable treatment and empowerment. This new form of interaction between 
government and civil society means that innovative entry points have been launched for direct public involvement in the process of government (TENDLER, 1997). Therefore, the debate about the direct involvement of ordinary people in the political structure has changed from a 'scaling up', an 'institutionalisation of participation' (CLEAVER, 2001) and participatory techniques possibly influencing the policy process (WORLD BANK, 2004) into a better understanding of the complex nature of interaction between individuals and the social structure.

Questions on how partnership has been used as a channel for building good governance and public accountability in the development and implementation of policy have arisen and focused attention on issues of equity and legitimacy. For instance, there are critical analyses on matters of representation and beneficiaries concerning issues such as who represents civil society and who is likely to benefit from the partnership (CLEAVER, 2004). The process of a broad-based popular involvement in political structures for good governance, transparency and public accountability has improved the effective targeting of resources and government awareness of local needs (WORLD BANK, 2004). However, this does not mean that this involvement will as a result bring about improvement for the most vulnerable communities (BOWYER, 2003).

As a goal, partnership improves the chances of direct democratic involvement in governance and public transparency and makes the relationship between local people and local government more direct (FLORISBELO; GUIJT, 2004; WORLD BANK, 2004). There is, however, no empirical evidence showing that partnership has brought about a shift in political power (CLEAVER, 2001). There is a notable lack of evidence that partnership can work as a policy for other local development strategies that bring together different groups pursuing a reconciliation of their diverse interests within the process of development. These are two important points that should be taken into account in future studies (CLEAVER, 2001).

While partnership efforts were failing to deliver power to the powerless, no one was paying attention to the implications of how organisational structures, management and procedures over partnership had affected the opportunities of ordinary people to act in their own favour (FOWLER, 2002). In this perspective, the next section debates how organisational factors influence partnership building and influence governance.

\section{Partunership and Organisarional Factors Influemcing Governance}

In this section our goal is to demonstrate how management structures and partnership procedures affect governance efficiency. This is because the literature (LOEWENSON, 2000; VASCONCELLOS SOBRINHO, 2009) shows that one of the greatest barriers to a more participatory form of local governance is the control of the structures and processes of partnership and the definition of agents, goals, agendas and events by government authorities. There are some examples in which local elites face opposition from the poor through the actions of grassroots organisations and social movements (VASCONCELLOS SOBRINHO, 2009). Nonetheless, in rural areas, where elites have historically held political power, there is no acknowledged definition of a clear participatory form of local governance. Although partnership stands for inclusion of groups from civil society in government structures, management and procedures, it is critical to know which government policies and practices are in place (VASCONCELLOS SOBRINHO, 2009).

A lack of evidence about improvements stemming from partnership in terms of reduction of inequality or of social exclusion suggests that there are important restraints in the change of direction from a top-down system to a more interactive form of social provision. This comprises the institutions, organisations and also politicians, managers, civil servants and rural workers who are involved in social organisations. They act based on organisational structures that in effect hinder a cultural move towards a more interactive process (LOEWENSON, 2000). In this sense, the capacity of ordinary people to protect their own interests in the process of partnership is likely 
to fail to have potentially effective innovations to produce enhanced participation in democratic governance (BOWYER, 2003).

Ambiguous goals, unclear roles of the parties involved, weak exchange of information and poor representation are mentioned as the most salient problems for partnership and management performance (BOWYER, 2003; VASCONCELLOS SOBRI$\mathrm{NHO}, 2009)$. In an analysis of public participation in the Zimbabwean health system, Loewenson (2000) suggests that for communities, rural workers, politicians and other important groups trying to agree on a locus of control, the use of partnership can also be unwelcome and divisive. A limited understanding of the meaning of partnership may have the result of making communities and the organisations representing them to hand over their power of decision making. Part of the problem is how governments conduct relationships with communities. As argued by Vasconcellos Sobrinho (2009), instead of treating communities as equal partners in the development process, the government treats them as beneficiaries of its programmes. While exercising state control over decision making and resources, the government blocks ordinary people from protecting their own interests and priorities. This suggests that the increase in the commitment to partnership is accompanied by a deficient operational understanding of the concept and a self-evident problem of translating it successfully into practice. Moreover, barriers such as a tradition of top-down planning, lack of social and organisational cohesion at community level, paternalistic standing of governmental rural workers and excessive bureaucracy of the rural sector are not encouraging (VASCONCELLOS SOBRINHO, 2009).

Growing numbers of areas such as Dhaka (AHMAD, 2006), London (BENNETT; KREBS, 1994) and Ourém (VASCONCELLOS SOBRINHO, 2009) have incorporated partnership into the government systems as a way to build a sense of 'shared responsibility' for society. Despite this narrow interpretation of the concept, partnership is more likely to be considered as a tool for the implementation of government programmes and actions than for the governance of social systems (VASCONCELLOS SOBRINHO, 2009).

Notwithstanding a failure to understand the concept and its impact on operational procedures, as explained by Vasconcellos Sobrinho (2009), it is accepted that partnership should be reinforced all across the rural world (VASCONCELLOS SOBRI$\mathrm{NHO}, 2009$ ). To be carried out as a participatory process with collective principles and mechanisms and procedures to achieve collective goals in the rural area, though, partnership requires an appropriate interpretation, its own methods and a committed government to promote it (VASCONCELLOS SOBRINHO, 2009). If this does not exist, partnership may lose its meaning and may not be able to give feedback to communities.

\section{Comelrusioms}

Based on a literature review, this paper has identified that in spite of its significance the historical background of partnership has not been included among the factors explaining the use of partnership in governance, particularly in developing countries. The lack of historical insights on partnership literature involving developing countries suggests that there is poor engagement with a reality in which political and legal institutions contribute to partnership building and particularly to partnership in a governance context. The literature has presented an effective discussion of the socio-political environment that goes beyond the partnership process.

The mechanisms created in the 1988 Brazilian National Constitution regarding people's participation in public policy making and the process of governance suggest that the socio-political environment is critical. This is because any useful discussion about the meaning of participatory mechanisms needs a context. In this paper we have attempted to show that an analysis of the factors underlying changes in attitude of state agencies and local organisations is of crucial importance. An assumption is made that public institutions matter in understanding the 'new' political space for cooperation. This is also important in understanding cooperation in areas that no longer have conflict between local government and local organisations. 
In spite of some inferences about a direct relationship between social capital and partnership, in this review of the literature we have identified that up to now there is no clear understanding of whether one set of organisations working through partnership is more effective than another set in protecting the powerless in rural development and in promoting a connection between state and local organisations for a governance process. This suggests that an analysis of partnership between organisations is likely to be based on information about organisations themselves and about their capacity to interact, to perform effectively in networks to achieve good governance. We show that the nature, function and structure of the organisations engaged in the interactive process is significant to examine to what extent they influence partnership between government and local organisations.

For effective social networks, an environment of local action with the participation of state, organisations and other institutions is expected not only to promote partnership for horizontal collective action, but also to support actions that result in social transformation.

By examining the means of partnership it is possible to assess its contribution to social transformation goals. In this sense, the commitment of both government agencies and local organisations to organisational restructuring and support for the creation of organisational mechanisms to work within a decentralised and multiplestakeholder decision making environment are relevant factors to be examined. It is then suggested in this paper that new research should deal with the meaning of partnership and with the commitment of the partners to carry out the meaning taken up by them.

In spite of the analytical conclusions that partnership brings about social benefits in its own right, there is no evidence that it effectively contributes to bringing power to the powerless. Partnership aims to make the relationship between local people and local governance stronger and improve the possibilities of the powerless to participate in local governance and to benefit from public transparency. However, there is no clear evidence that partnership brings about a shift in political power. Despite an obligation by State to make rural powerless people able to defend their needs and interests, it is not right to assert that their participation in planning and process that the rural dwellers have now increased their power over decisions and policies affecting their lives. Furthermore, it is still difficult to understand whether or not partnership works as a strategy to include the interests of powerless people in social development strategies.

Finally, in this paper we have attempted to show that it is unclear whether the interaction between ordinary people and the state in a participatory process has successfully helped to build social cohesiveness for different social groups and interests or not. A challenge that is posed by partnership is how to build partnerships in situations in which entitlements of different categories of people are so diverse. This suggests that the reconciliation of different interests and priorities of the diverse groups involved is not automatically favoured by a strategy of partnership.

\section{Bibliogreatpliny}

AHMAD, M.M. The partnership between international NGOs (Non-Governmental Organisations) and local NGOs in Bangladesh. Journal of International

Development, n. 18, p. 69-638, 2006.

BARTH, J. Public policy management councils in Brazil: how far does institutionalised participation reach? Public Administration and Development, n. 26, p. 253-263, 2006.

BENNETT, R.J.; KREBS, G. Local economic development partnerships: an analysis of policy networks in EC-LEDA local employment development strategies. Regional Studies, n. 28, p.119-140, 1994.

BLAIR, H. Participation and accountability at the periphery: democratic local governance in six countries. World Development, n. 28, p. 21-39, 2000. 
BOVAIRD, T.; LOEFFLER, E. Communities, trust, and organisational responses to local governance failure. In: WATSON, S.; MORAN, A. (Org.). Trust, risk and uncertainty. New York: Palgrave Macmillan, 2005. p.143 -164.

BOWYER, T.J. Popular participation and the state: democratising the health sector in rural Peru. Thesis (PhD) - University of London, London, 2003.

BRINKERHOFF, J. M. Partnership for international development. London: Lynne Rienner Publishers, 2002.

CAMAROTTI, I. SPINK, P. K. (Org.). Parcerias e pobreza: soluções locais na construção de relações sócio-econômicas. Rio de Janeiro: FGV, 2000.

CARNEY, D. Management and supply in agricultural and natural resources: is decentralisation the answer? ODI Natural Resources Perspectives, n. 4, p. 1-12, 1995.

CHAMBERS, R. Rural development: putting the last first. London: Longman, 1983.

CLEAVER, F. Institutions, agency and the limitations of participatory approaches to development. In: COOKE, B.; KOTHARI, U. (Org.). Participation: the new tyranny? London: Zed Books, 2001. p. $36-65$.

Paradoxes of participation: questioning participatory approaches to development. Journal of International Development, n. 11, p. 597-612, 1999.

COLEMAN, J.S. Foundations of social theory. London: Harvard University, 1990.

DFID. Millennium development goals: aid, trade, growth \& global partnership.

London: DFID. Disponível em: (www.dfid.gov.uk/mdg/aid.aso). Acesso em: 10 out. 2006.

ENGBERG-PEDERSEN, L. The limitations of political space in Burkina Faso: local organisations, decentralisation and poverty reduction. In: WEBSTER, N.; ENGBERGPEDERSEN, L. (Org.). In the name of the poor: contesting political space for poverty reduction. London: Zed Books, 2002. p.157-182.

EVANS, P. Government action, social capital and development: reviewing the evidence on synergy. In: EVANS, P. (Org.). State-society synergy: government and social capital in development. Berkeley: University of California, 1997. p.178-210.

FERREIRA, S. Public-private partnership in Angola: the case of development workshop and the water company. Dissertação (Mestrado em Estudos do Desenvolvimento) - Centro de Estudos do Desenvolvimento, University of Wales Swansea, 2003.

FINE, B. Social capital versus social theory: political economy and social science at the turn of the millennium. London: Routledge, 2001.

FLORISBELO, G.R.; GUIJT, I. Participatory municipal development plans in Brazil: divergent partners constructing common futures. In: HICKEY, S.; MOHAN, G. (Org.). Participation: from tyranny to transformation? Exploring new approaches to participation in development. London: Zed Books, 2004. p. 190-204.

FOWLER, A. Striking a balance: a guide to enhancing the effectiveness of nongovernmental organisations in international development. London: Earthscan, 1997.

Authentic NGDO partnerships in the new policy agenda for international AID: dead end or light ahead. Development and Change, n. 28, p.137-159, 1998.

Assessing NGO performance: difficulties, dilemmas and a way ahead.

In: EDWARDS, M.; . (Org.). The Earthscan reader on NGO management. London: Earthscan, 2002. p.293-307.

FOX, J. How does civil society thicken? The political construction of social capital in rural Mexico. In: EVANS, P. (Org.). State-society synergy: government and social capital in development. Berkeley: University of California, 1997. p.119-149. 
GAVENTA, J. Towards participatory governance: assessing the transformative possibilities. In: HICKEY, S.; MOHAN, G. (Org.). Participation: from tyranny to transformation? Exploring new approaches to participation in development. London: Zed Books, 2004. p. 25-41.

GIDDENS, A. Modernity and self-identity. Cambridge: Polity Press, 1991.

HARRISS, J. Working together: the principles and practice of co-operation. In: ROBINSON, D.; HEWITT, T.; HARRISS, J. (Org.). Managing development: understanding inter-organizational relationships. London: Sage and The Open University, 2000. p. 225-242.

HODGETT, S.; JOHNSON, D. Troubles, partnerships, and possibilities: a study of the making Belfast work development initiative in Northern Ireland. Public Administration and Development, n. 21, p. 321-332, 2001.

ISHAM, J.; KELLY, T. et al. Social capital and economic development: well-being in developing countries. Cheltenham: Edward Elgar, 2002.

JOHNSON, H.; WILSON, G. North-south/south-north partnerships: closing the mutuality gap. Public Administration and Development, n. 26, p. 71-80, 2006.

$\mathrm{KOHL}, \mathrm{B}$. Democratizing decentralization in Bolivia: the law of popular participation. J. Plan. Educ. Res., n.3, p. 153-164, 2003.

LEWIS, D. Building 'active' partnership in aid-recipient countries: lessons from a rural development project in Bangladesh. In: OSBORNE, S. P. (Org.). Public-private partnerships: theory and practice in international perspective. London: Routledge, 2000.p.252-264.

LOEWENSON, R. Public participation in health system in Zimbabwe. IDS Bulletin, $\mathrm{n}$. $31,2000$.

MCQUAID, R.W. The theory of partnership: why have partnerships? In: OSBORNE, S. P. (Org.). Public-private partnerships: theory and practice in international perspective. London: Routledge, 2000. p.9-35.

MEHROTRA, S. Governance and basic social services: ensuring accountability in service delivery through deep democratic decentralization. Journal of International Development, n. 18, p. 263-283, 2006.

OSTROM, E. Crossing the great divide: co-production, synergy, and development. In: EVANS, P. (Org.). State-society synergy: government and social capital in development. Berkeley: University of California, 1997. p.85-118.

PUTNAM, R. Making democracy work: civic tradition in modern Italy. Princeton: Princeton University Press, 1993.

RIBOT, J.C. Democratic decentralisation of natural resources: institutional choice and discretionary power transfer in Sub-Saharan Africa. Public Administration and Development, n. 23, p. 53-65, 2003.

RONDINELLI, D.A. Decentralisation and development. In: HUQUE, A. S.;

ZAFARULLAH, H. (Org.). International development governance. London: Taylor \& Francis, 2006. p.391-404.

SEN, A. Development as freedom. Oxford: Oxford University Press, 1999.

SMOKE, P. Decentralisation in Africa: goals, dimensions, myths and challenges. Public Administration and Development, n. 23, p. 7-16, 2003.

SPINK, P. K.; CLEMENTE, R.; KEPPKE, R. Governo local: o mito da descentralização e as novas práticas de governança. Revista de Administração da USP, São Paulo, v.34. n.1, p.61-69, 1999

STREN, R.; CAMERON, R. Metropolitan governance reform: an introduction. Public Administration and Development, n. 25, p. 275-284, 2005. 
TENDLER, J. Good governance in the tropics. Baltimore: John Hopkins, 1997.

THOMPSON, S. Trust, risk and identity. In: WATSON, S.; MORAN A. (Org.). Trust, risk and uncertainty. New York: Palgrave Macmillan, 2005. p.26-46.

TORO, J. B. A construção do público: cidadania, democracia e participação. Rio de Janeiro: SENAC Rio, 2005.

VASCONCELLOS SOBRINHO, M. Partnership for local development: the relationship between local organisations and government in two areas of North-East Pará, Amazonia, Brazil. Saarbrücken: VDM Verlag Dr. Müller, 2009.

WORLD BANK. Public-private partnership. Washington: World Bank. Disponível em: (http://rru.worldbank.org). Acesso em: 12 dez.2005.

WORLD BANK. States-Society synergy for accountability. Washington: World Bank, 2004.

Artigo recebido em 27/11/2009.

Última versão recebida em 10/02/2011.

Artigo aprovado em 05/05/2011. 